\title{
"Most of the Haggadot Are Only Opinions": Cambridge University Library T-S Misc.35.14
}

\author{
BEN OUTHWAITE \\ Genizah Research Unit, Cambridge University Library, Cambridge, UK \\ E-mail:bmo10@cam.ac.uk
}

\begin{abstract}
This essay examines the language and diplomatics of a single medieval Hebrew letter by one of the leading letter writers of the Cairo Geniza, Solomon b. Judah, gaon of the Jerusalem academy in the eleventh century. The letter, composed and written by Solomon himself, is addressed to the head of the rival Babylonian faction in Egypt, Sahlān b. Abraham, with whom he enjoyed an often fraught professional relationship. It deals with a number of matters, including the transfer of charitable funds from North Africa to the poor of Jerusalem and the gaon's opinion of popular biblical exegesis. Solomon b. Judah is one of the most elegant Hebrew stylists to emerge from the documentary corpus of the Cairo Geniza, and his letters provide an important window on the Palestinian gaonate and its relations with Egypt in the second quarter of the eleventh century.
\end{abstract}

Keywords Geniza $\cdot$ Medieval Hebrew $\cdot$ Palestine $\cdot$ Diplomatics $\cdot$ Gaonate

The Cairo Geniza preserves hundreds of letters written in Hebrew, a language that was, throughout the time that the Geniza was in use, a liturgical and scholarly idiom but not a spoken vernacular. The letters fall into three broad time periods. We find considerable numbers in the earliest period, from the tenth century, before Hebrew was supplanted in correspondence by JudeoArabic over the course of the second half of the eleventh century. Hebrew letters surface again in the thirteenth century, principally owing to the arrival into the upper echelons of the Jewish community of Egypt of a number of Europeans who were unable to communicate in Arabic. This apparent revival lasted only for that first non-Arabicized generation. Finally, letters in the Holy Tongue turn up in large numbers following the Ottoman invasion of Egypt in the sixteenth century, written by Jews of originally Spanish origin who were, again, unfamiliar with Arabic. The Hebrew of the earliest period, the tenth and eleventh centuries, marks a high-water mark in the history of the language in the Middle Ages and mirrors the contemporary vitality of Hebrew liturgical poetry. The motivation for writing correspondence in Hebrew - the result of a number of factors - was principally related to the prestige of the language and its place in Jewish religious life. The educational system in use by the Jews of Islamic lands stressed the learning of Hebrew-essential for reading the Bible, the duty of every Jew-and consequently equipped the educated with a basic reading and writing knowledge 
of the language. The centers of Jewish governance, the academies (yeshivot), enjoying a cultural and political resurgence under Islamic rule, also pushed the prestige of the Holy Language and used it for written communication. Behind this use was the fact that much of this communication was intended for public recitation in the synagogue, formal notices to be read in "all the ears of the people," and in the synagogue only Hebrew and Aramaic were deemed acceptable. ${ }^{1}$ As the centers of Jewish governance declined in the eleventh century, the use of Hebrew as a communicative idiom dried up, and Maimonides's ruling (in the twelfth century) that vernacular languages - that is, Arabic - could be used in the synagogue service shows the extent to which knowledge of Hebrew, and the application of that knowledge, had also declined. $^{2}$

The letter edited below is from the head of the Jerusalem yeshiva, the gaon Solomon ben Judah, to the head of the Babylonian community in Egypt, Sahlān ben Abraham. No other writer of Hebrew letters has left such a legacy in the Geniza as Solomon b. Judah, who headed the academy for a quarter of a century until his death in $1051 \mathrm{CE}$. This letter, typical in many ways of the nearly one hundred of his letters preserved in the Geniza, deals with two different matters. Communications between Egypt and Palestine, a frontier land, were often difficult, and letters could take weeks to arrive, so it was necessary to include as much business as possible in each one. In this case, after polite necessities, the gaon thanks Sahlān for forwarding a donation to the poor of Jerusalem with his last letter. (Although at times political rivals, the two communities-Palestinian and Iraqi-often collaborated in administering Jewish charitable foundations and assisting the indigents of Jerusalem.) He then moves on to a second, more personal matter: Sahlān had asked Solomon to copy some passages of a midrash on the Song of Songs for him. The gaon demurs, being unwilling to borrow the book required, and justifies his decision on the grounds that he has a rationalistic outlook on biblical interpretation - an outlook shared by the general public. He assures Sahlān, who presumably sought the text to inform his sermonizing, that contemporary audiences would no longer look favorably on the antique and overly figurative method of interpretation that such midrashim exemplify.

\footnotetext{
${ }^{1}$ Solomon ben Judah, the head of the Jerusalem academy, asserted his authority through public readings, as can be seen from T-S 20.181, a letter in which he explains that he sent the addressee, the leader of the Jerusalemite congregation in Fustat, three letters, the third of which was for public declamation: והגליון הארוך החתום להקראות באזני כל העם, "and the long sealed sheet is to be read into the ears of all the people."

${ }^{2}$ On the use of Hebrew in correspondence in the Cairo Geniza, see Ben Outhwaite, "Lines of Communication: Medieval Hebrew Letters of the Eleventh Century," in Scribes as Agents of Language Change (Studies in Language Change, vol. 10), ed. Esther-Miriam Wagner, Ben Outhwaite, and Bettina Beinhoff (Berlin, 2013), 183-98.
} 
This letter is written on Egyptian or Palestinian paper measuring approximately $26.8 \times 18.5$ centimeters, in the gaon's own distinctively square and serifed hand. Solomon wrote his letter on one side of the sheet of paper, signing his name at the bottom, and then folded it up multiple times along its length before writing the address on the verso, on the exposed fold. There is no evidence that it was sealed. The address is in Arabic script, again written by Solomon, suggesting that the carrier of the letter on this occasion may have been not a Jew but perhaps a Muslim or a Christian merchant making a trip to Egypt from the Holy Land. (Letters are found with addresses in Hebrew, Judeo-Arabic, and Arabic and sometimes a combination of languages and scripts, and it can be assumed that these reflect the linguistic competence of the letter's intended carrier.) ${ }^{3}$ The letter was written either in Ramla or in Jerusalem around $1048 \mathrm{CE}$, toward the end of Solomon's rule as the Palestinian gaon.

\section{Cambridge University Library T-S Misc.35.14}

\section{Transcription}

Recto

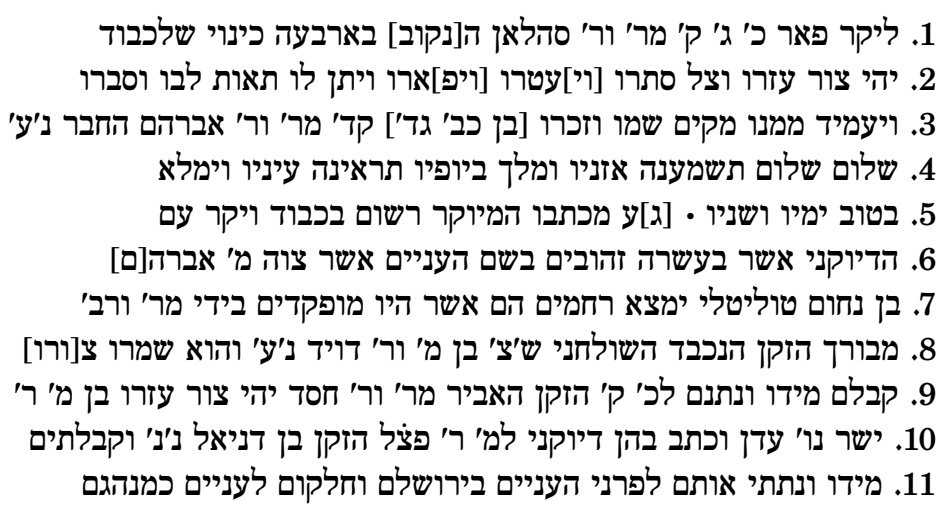

${ }^{3}$ On the addressing of letters and other features of their layout, in both Hebrew and JudeoArabic, see Esther-Miriam Wagner and Ben Outhwaite, “'These two lines...': Hebrew and Judeo-Arabic Letter-Writing in the Classical Genizah Period," in Beyond Free Variation: Scribal Repertoires from the Old Kingdom to Early Islamic Egypt, ed. J. Cromwell and E. Grossman (Oxford, 2018), 314-32.

${ }^{4}$ This manuscript has been edited before. See Jacob Mann, Texts and Studies in Jewish History and Literature, 2 vols. (Cincinnati, 1931-53), 1:320-22; and Moshe Gil, Palestine during the First Muslim Period (634-1099) (in Hebrew), 3 vols. (Tel Aviv, 1983), 2:261-63. However, the readings given here differ from both these editions in a number of places. The letter can be seen at https://cudl.lib.cam.ac.uk/view/MS-TS-MISC-00035-00014/1. 


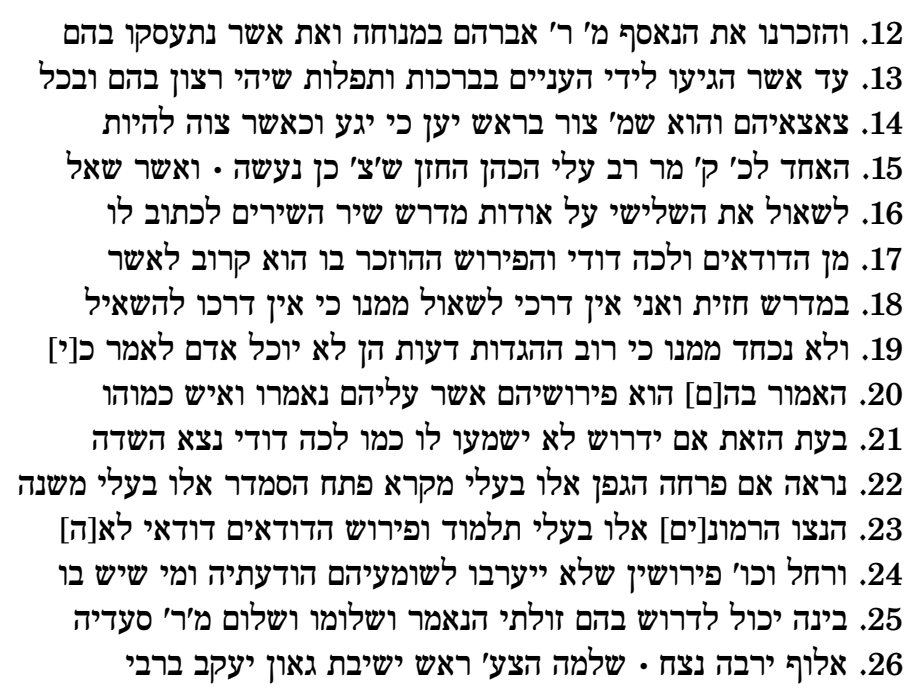

Verso

$$
\begin{aligned}
& \text { 1. لسيدي رأس الكل ابو عمر سهلان بن ابر هيم من محبه لا عدمه } \\
& \text { 2. اطل الله بقاه و ادام عزه وتأييده وسعال[ته ونعمه] ] الفسطاط ان شاء الله }
\end{aligned}
$$

\section{Translation}

Recto

1. To the dear, glorious, honorable, great, holy, our master and teacher Sahlān, who is distinguished with four titles of honor-

2. may the Rock be his aid and his shelter's shade and crown him and glorify him and give him his heart's desire and his hope

3. and may He raise up from him another to perpetuate his name and his memory-[son of the honorable, great,] holy, our master and our teacher Abraham the Haver-his rest be in Eden.

4. May his ears hear only greetings and his eyes see the king in his beauty. May He fill

5. his days and his years with prosperity. His highly esteemed letter arrived, inscribed in honor and glory, with

6. the money order for ten dinars in the name of the poor that had been commissioned by master Abraham

7. ben Nahum the Toledan-may he find mercy. These were the ones that had been consigned to the hands of our master and our teacher

8. the banker Mevorakh, the esteemed elder-God preserve him-son of our master and teacher David-his rest be in Eden. He-the Rock preserve $\operatorname{him}-$ 
9. received them from his hand and gave them to the honorable, holy and mighty elder, our master and teacher Hesed—let the Rock be his aid—son of our master and teacher

10. Yashar-his rest be in Eden - and he wrote a money order to the value [of the coins] for our master and teacher Fadl the elder, son of Daniel—whose soul is at rest-and I received them

11. from his hand and I gave them to the officials responsible for the poor ${ }^{5}$ in Jerusalem. They distributed them to the poor according to their usual practice.

12. We commemorated the deceased, our master and teacher Abraham, now at rest, and those who were involved with

13. getting [the money] into the hands of the poor, with blessings and prayers that [divine] favor be bestowed on them and on all

14. their descendants. And he (the addressee) — the Rock preserve him-is [blessed] at the head of the list because of his hard toil. And when he ordered that

15. a single (dinar) go to Eli ha-kohen the cantor-the Rock preserve himso it was done. And as for his request

16. to ask the Third ${ }^{6}$ about the midrash on the Song of Songs, that he write for him (the interpretations)

17. from "the mandrakes" (Song of Songs 7:13) and "come, my beloved" (Song of Songs 7:11), well, the interpretation expressed there is close to that 18. in the Midrash Hazita ${ }^{7}$ and I myself am not accustomed to asking him (for books) for he is not accustomed to lending (them).

19. It should be no secret to us that most of the haggadot ${ }^{8}$ are [only] opinions: no one can say that

20. what is said in them is really the original interpretation that was given. If someone were

21. now to interpret them [in the same way], people wouldn't listen to him. For example, in the section "Come, my beloved, let us go out into the field,"

\footnotetext{
${ }^{5}$ The "officials responsible for the poor" are the parnasim, פרנסי העניים, here miswritten פרני, a rare error from the careful Solomon. On the parnasim, see Mark R. Cohen, Poverty and Charity in the Jewish Community of Medieval Egypt (Princeton, NJ, 2005), 211-16.

6"The Third" is a rank in the Palestinian academy, lit. "The Third [in line]" after the gaonthe head of the academy - and the av bet din, "the head of the court," who was the gaon's deputy (and often his successor). On the organization of the Palestinian academy, see Moshe Gil, A History of Palestine, 634-1099, trans. Ethel Broido (Leiden, 1992), 505-8.

${ }^{7}$ An exegetical midrash on the Song of Songs, also known as the Song of Songs Rabba or Aggadat Hazita, the latter after its first word, חזית, a quotation from Prov. 22:29 "Do you see ...?"

${ }^{8}$ By which he means the aggadic commentaries on the Bible, which were the creations of the Palestinian rabbinic tradition.
} 
22. the phrase "see whether the vines have budded" refers to scholars of the Bible; the phrase "whether the grape blossoms have opened" refers to scholars of the Mishnah;

23. "and the pomegranates are in bloom" refers to scholars of the Talmud. And the interpretation of "the mandrakes"- they are the mandrakes of Leah and

24. Rachel etc. I am giving (him) some interpretations that will not please those who hear them. Anyone of

25. intelligence can give interpretations different from what is said (in the aggadic midrashim). May his well-being and the well-being of our master and teacher Sa'adya,

26. [the] Alluf, ${ }^{9}$ increase forever. Solomon the younger, Head of the Yeshiva "the Pride of Jacob," 10 son of a scholar. ${ }^{11}$

\section{Verso}

1. To my lord the Rosh Kalla ${ }^{12}$ Abū 'Amr Sahlān bin Ibrahīm. From his friend - may [his friend] not be deprived of him.

2. May God extend his existence. May he perpetuate his glory, his support, his happiness and his prosperity. [To] Fustat, God willing.

\section{Notes and Comments}

The structure of Hebrew letters differs depending on who is sending them, who is receiving them, and their purpose, but they often open with a lengthy preamble (also called a praescriptio) in which blessings are bestowed on the

\footnotetext{
${ }^{9} \mathrm{~A}$ title in the Babylonian academies of Iraq, "chief," which was also given out to leading members of the Babylonian community in the diaspora. See Robert Brody, The Geonim of Babylonia and the Shaping of Medieval Jewish Culture, with a new preface and an updated bibliography (New Haven, CT, 2013), 48-50.

ישיבת גאון יעקב, "Academy of the Pride of Jacob," was the formal title of the Palestinian academy, derived from Ps. 47:5:"He chose our heritage for us, the pride of Jacob whom He loves. Sela." Yeshivat Ga'on Ya'akov was in fact a title used by all three academies, Pumbeditha, Sura, and Jerusalem, but the Iraqi academies were also referred to as ישיבה שלגולה, "Academy of the Exile," whereas the Palestinian academy was known as ישיבת צבי or "' ישיבת ארץ צבי "the Academy of [the Land of] Beauty," after Dan. $11: 16,41$.

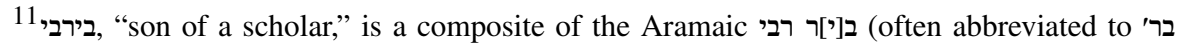
or ביר). In his Jewish Marriage in Palestine: A Cairo Geniza Study, 2 vols. (Tel Aviv, 1980), 2:411-15, Mordechai Akiva Friedman has a thorough discussion of the origins and use of the term.

${ }^{12}$ A title from the Babylonian academies, "Head of the Row"; see Brody, The Geonim of Babylonia, 49-50.
} 
recipient, frequently in poetic style. This may be followed by a greetings section, where the sender of the letter introduces himself or herself, often using a formulaic phrase, although this can also just introduce the recipient. The business of the letter is usually introduced at this point, with a suitable transitional phrase. Further blessings usually follow after the business is concluded, and these may be extended to friends, colleagues, and family of the recipient. The sender's name is placed either at the very end or at the very top of the leaf, the latter being the usual practice with many of the Babylonian and Palestinian geonim.

The length and style of the preamble depends on the relationship between author and recipient, their relative social status, and the purpose of the letter. The greater the rank of the recipient, the more flowery the letter can be in its opening. Depending on the skill of the writer, the letter can open with citations from the Bible, rhymed prose, brief poetic compositions, or a combination of all of these. Letters intended to be read aloud in the synagogue can have extremely lengthy and finely wrought preambles. In the present case, however, the letter is polite but not overly so since Solomon and Sahlān were frequent correspondents and Solomon - the venerable incumbent of the gaonate of Jerusalem-would have viewed himself as the social superior. Furthermore, although the letter contains information to be passed on to the wider community - about the successful distribution of funds to the poor-it was a private communication with Sahlān and probably not intended to be read aloud.

Common terms of address in letters are often written in abbreviated form, particularly if the correspondents were used to writing to each other. Here,

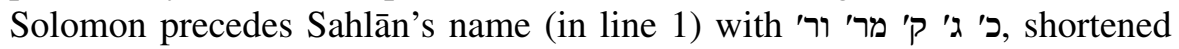
forms of three construct nouns, כבוד גדולת קדושת, "the honor of, the greatness of, the holiness of" - a polite epistolary mode of address-followed by the usual titles for a scholar,מרנו ורבנו (sometimes in their Aramaic form, מרנא ורבנא (מ) "our master and teacher." A sequence of abbreviated nouns (in line 3) is used before Sahlān's father's name, Abraham, as before Sahlān's own name earlier. As is typical of the letter writing of the period, Solomon avoids writing the same phrase in an identical manner, preferring to abbreviate pas in line 1. Abraham has the title "the Haver" after his name. Haver, or "member [of the academy]," was a title awarded by the Jerusalem yeshiva. In the interest of intercommunal relations, the yeshiva had awarded the title to Sahlān's father even though he was a leading member of the Babylonian (Iraqi) community of Fustat, the competing Rabbanite faction. $^{13}$

\footnotetext{
${ }^{13}$ On Abraham's titles, see Elinoar Bareket, Fustat on the Nile: The Jewish Elite in Medieval Egypt (Leiden, 1999), 228-29.
} 
The blessing that follows Sahlān's name (in line 2), שמרו צורו (or, without the possessive suffix, שמרו צור), "His Rock preserve him," is very common in medieval documents. "The Rock" is a figurative epithet for the deity derived from the Bible, for example, 2 Samuel 22:47. Such blessings are dictated by politeness: it is rare to mention living individuals without wishing them well. Furthermore, Solomon shows off his skill in Hebrew by rhyming the blessings in - $o$, taking advantage of medieval Hebrew's leveling of the thirdperson suffixes across nouns and verbs. ${ }^{14}$ The blessing is abbreviated to (line 8). When the blessing occurs later in the line, Solomon avoids repeating himself so soon and writes it in full, שמרו צור(ו. ${ }^{15}$ When, in line 14, he comes to write it again, he gives yet a further form, שמ' צור, before returning to ' $\boldsymbol{y}^{\prime}$ in line 15. As with the living, mentions of the dead also require a suitable blessing. After mentioning Abraham, Solomon inserts the abbreviated postmortem blessing נוחו עדן, "his rest be in Eden." He employs a different postmortem blessing after David's name later in the letter (line 10), ' 'J', an abbreviation of נוח נפש, "whose soul is at rest."

Note that throughout the letter Solomon refers to his correspondent respectfully in the third person. This is often the case in letters of the classical Geniza period, but the second person also occurs, and sometimes letters can slip in between the two forms, though it is not always possible to tell whether this is by accident or by design.

The break from the preamble to the business of the letter is marked with a single dot (line 5). In this Solomon is more formal than many writers, who tend not to use any punctuation. He also employs the dot in line 15 to mark the change of topic, from the distribution of the funds for the poor to the question of the interpretation of the Song of Songs. Letter writers use a number of different phrases to introduce the business of a letter. Popular ones include the biblical hapax legomenon מגמת, "purpose, thrust," for example, מגמת מכתבנו זה, "the purpose of this our letter"; 16 forms of the verb "מתב "to write," for example, נכתבו טורים אלה, "these lines have been written",17 and forms of the verb ידע, "to know," for example, ומודיעים לך יקירנו, "and we are informing you, our dear one." 18

Some items of Hebrew vocabulary stand out. The generic term זהובים, "gold coins," is preferred over the precise type of coinage, the Islamic dinar.

\footnotetext{
${ }^{14}$ On the leveling of suffixes in epistolary Hebrew, see Ben Outhwaite, "Gaonic Correspondence," in Encyclopedia of Hebrew Languages and Linguistics, ed. Geoffrey Khan, http://dx.doi.org/10.1163/2212-4241_ehll_EHLL_COM_00000646.

${ }^{15}$ Since the end of the line is lost, it is not clear whether the final vav is present.

${ }^{16} \mathrm{~T}-\mathrm{S}$ 13J19.15, a letter sent from Ashkelon ca. $1025 \mathrm{CE}$.

${ }^{17} \mathrm{~T}$-S 13J9.2, a letter by Solomon to the head of the Palestinian Jewish community in Fustat.

${ }^{18} \mathrm{~T}-\mathrm{S}$ 16.261, a letter from Solomon but in the hand of his son, Abraham, betrays more of the son's style, including the second-person address and a greater use of formulaic expressions.
} 
Other writers sometimes similarly refer to dinars by the archaic term דרכמונים, "drachmas," most popular in legal documents of the Karaite community. A feature of the Hebrew letters of the classical period is an avoidance of Arabic loanwords in favor of finding suitable Hebrew terms from the wealth of rabbinic literature. ${ }^{19}$

At the end of the letter Solomon signs himself "Solomon the Younger," with "the Younger," הצעיר, abbreviated. It is not a sign of age but a pretension to modesty. Those who share a name with a leading biblical figure sometimes add "the Younger" or "the Smaller" after their names as a mark of humility, conceding that they are not the most significant individual to bear the name. Solomon concludes his signature with "son of a scholar," the composite term בירבי , and leaves off the name of his father, Judah, which would normally follow. ${ }^{20}$ In this he is not alone: it appears to have been an affectation of leading members of the Palestinian Jewish community, who, being well-known enough, did not feel the need to mention the name of their father. Josiah $b$. Aaron, who was the Palestinian gaon from ca. 1000 to 1025, also did not יאשיהו ראש ישיבת גאון יעקב mention his father's name, preferring to sign as בירבי, "Josiah Head of the Yeshiva 'the Pride of Jacob,' son of a scholar."21 Members of the Palestinian community in Egypt mostly did not adopt the style: Eli b. 'Amram, for instance, the head of the Jerusalemite community in Fustat in the middle of the eleventh century, signs himself עלי החבר בסנה "Eli the Haver in the Great Sanhedrin son of the scholar "Amram." 22

Letters do not always close with signatures. It was the custom among the earlier Palestinian and Babylonian geonim to open a letter with the sender's name and titles. In a letter from Nehemiah (960-68 CE), the gaon of Pumbedita, Iraq, that still preserves its gaonic bulla attached to the bottom, the gaon writes [... נחמיה הכהן ראש ישיבה שלגולה בן, Nehemiah ha-Kohen Head of the

\footnotetext{
${ }^{19}$ Though they may be Greek, Latin, or Persian loanwords that entered into Hebrew at an earlier period. See Outhwaite, "Gaonic Correspondence"; and Ben Outhwaite, "A Descriptive Grammar of the Medieval Hebrew of the Cairo Geniza Letters" (PhD diss., Cambridge University, 2000), 98-99.

${ }^{20}$ Earlier in his career, Solomon did usually give his full name. In $1025 \mathrm{CE}$, while still the academy's av bet din, he signed a letter שלמה אב הישיבה בי[רבי] יהודה, "Solomon Av of the Yeshiva son of the scholar Judah" (T-S 12.80). But in another display of modesty he added a biblical motto in tiny letters around his signature-again, a fashion found in wide use in the early eleventh century-from Ps. 22:7, "But I am a worm and not a man." About three years into his reign as gaon, Solomon begins to leave his father's name off his signature. Bodl. MS Heb. a3.3, a letter sent by the gaon in $1028 \mathrm{CE}$, ends with just "son of a scholar" but also has "But I am a worm and not a man."

${ }^{21} \mathrm{~T}-\mathrm{S}$ 13J1.2, a legal document from $1015 \mathrm{CE}$.

${ }^{22} \mathrm{~T}-\mathrm{S} 18 \mathrm{~J} 4.21$, a letter from Eli explaining a point of law to a provincial judge.
} 
yeshiva of the Exile son of [... ${ }^{, 23}$ Solomon's switch to signing the end of his letters marks a definite break with gaonic tradition and may owe something to his Maghribi origins-he was from Fez originally. An elegant and lengthy letter of the famed Tunisian scholar Hushi'el b. Elhanan, written on parchment and sent to Egypt from Qayrawān around 1000 CE, has Hushi'el's signature at the very end, not the top. ${ }^{24}$

When the name of the sender occurs at the beginning of the letter, the end of the letter may receive his 'aläma, or motto, a habit borrowed from Islamic custom. This is also the practice in notes where the name of the sender may not be mentioned at all. For instance, Sahlān ben Abraham's note to a colleague in Fustat detailing how to deal with a woman who refused to attend ברית court is in his handwriting but is not signed. It concludes with his motto תם, "a covenant of integrity." 25 The 'alāma is also often used in the address on the back of letters, particularly when the sender's name is not given there. ${ }^{26}$

Publisher's Note Springer Nature remains neutral with regard to jurisdictional claims in published maps and institutional affiliations.

Open Access This article is distributed under the terms of the Creative Commons Attribution 4.0 International License (http://creativecommons.org/licenses/by/4.0/), which permits unrestricted use, distribution, and reproduction in any medium, provided you give appropriate credit to the original author(s) and the source, provide a link to the Creative Commons license, and indicate if changes were made.

\footnotetext{
${ }^{23}$ Mosseri VIII.479. Josiah, the Palestinian gaon, also puts his name at the top of the letter, e.g., T-S 13J26.16, which is from about $1015 \mathrm{CE}$.

${ }^{24} \mathrm{~T}-\mathrm{S}$ 28.1, one of Schechter's exciting early discoveries in the documentary Geniza. See Solomon Schechter, "Geniza Specimens: A Letter of Chushiel," Jewish Quarterly Review 11, no. 4 (1899): 643-50; and Ben Outhwaite, "Schechter's Eye for the Extraordinary," Jewish Historical Studies 48 (2016): 34-45, esp. 39-40.

${ }^{25}$ T-S 13J16.11. The motto is Borit Tom, two nouns, and not as given in Gil, A History of Palestine, 580, berit tam. Not only would this be ungrammatical (and thus unbefitting of the erudite Sahlān), but a Babylonian $o$ vowel can also be seen above the תם.

${ }^{26}$ See, e.g., T-S 16.261, a letter sent by Solomon b. Judah (though penned by his son). His name is at the end of the letter on the recto, but the verso contains only the recipient's name and Solomon's motto, ישע רב, "a great deliverance."
} 